I. В. Драпак

\title{
Фармакофорне моделювання діуретичної активності похідних 1,3-тіазолу та 1,3,4-тіадіазолу
}

Львівський національний медичний університет імені Данила Галицького

Ключові слова: фармакофорне моделювання, похідні 1,3-тіазолу та 1,3,4-тіадіазолу, діуретична активність

Фармакофорне моделювання є одним з перспективних напрямів комп'ютерної підтримки розробки ліків (ComputerAided Drug Design). Цей метод дозволяє встановити набір і взаємне розташування специфічних молекулярних фрагментів, які необхідні для прояву біологічної активності $[1,2]$. Результат вдалого фармакофорного моделювання зазвичай співпадає 3 конфігурацією активного сайту відповідної біомішені, на яку діють сполуки, використані для моделювання. Таким чином, фармакофорне моделювання можна розглядати як процедуру моделювання рецептора на основі даних щодо активності речовин, які з цим рецептором зв'язуються $[3,4]$. Крім надання важливої інформації про структурні реквізити, необхідні для прояву певної біологічної активності, фармакофорна модель може надалі використовуватись як шаблон для так званого фармакофорного скринінгу - просіювання великих баз даних сполук з метою відкидання завідомо неактивних молекул і вибору тих речовин, які вартують синтезу та подальших досліджень. I навпаки, маючи розроблені набори фармакофорних моделей, можна здійснювати підбір моделей, які узгоджуються з структурою конкретної синтезованої речовини. Це дає змогу вибрати напрями для проведення пошуку біологічного ефекту, який може мати дана речовина [5].

Мета дослідження - фармакофорне моделювання похідних 1,3-тіазолу та 1,3,4-тіадіазолу для цілеспрямованого пошуку потенційних діуретиків.
Матеріали та методи. База даних для процедури фармакофорного моделювання складалась з 17 речовин - похідних 1,3-тіазолу та 1,3,4-тіадіазолу (рис. 1) 3 встановленою діуретичною активністю in vivo за методом Є. Б. Берхіна, а також двох відомих діуретиків - гідрохлортіазиду та ацетазоламіду, діуретична активність яких була визначена у тих самих експериментальних умовах за однаковою методикою [6, 7]. Сполуки вважали активними, якщо їхня діуретична дія перевищувала або дорівнювала діуретичному ефекту ацетазоламіду, який становив 4,90 мл/100 г.

Для моделювання фармакофора, відповідального за прояв діуретичної активності в ряду досліджених сполук, використовували комп'ютерну програmy MOE (Molecular Operating Environment) [8]. Алгоритм пошуку фармакофорних центрів працює в декілька етапів і включає генерацію енергетично стійких конформерів, ідентифікацію потенційних фармакофорних центрів у згенерованих конформерах, послідовний пошук таких комбінацій фармакофорних центрів, які будуть мати найкращу точність дискримінації між активними та неактивними сполуками. Конформери генерували в силовому

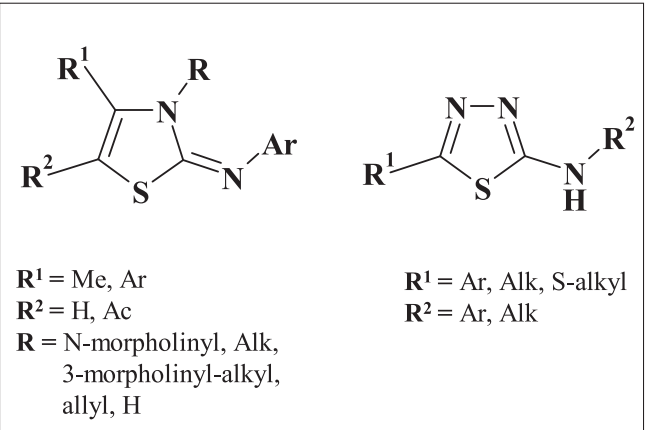

Рис. 1. Структура досліджуваних сполук 
полі MMFF94x методом стохастичного пошуку. Критерієм зупинки процедури мінімізації енергії конформера було досягнення коренем середньоквадратичного відхилення градієнта (RMSgradient) значення, меншого від 0,001. Конформери, внутрішня енергія яких перевищувала мінімальне значення для даної сполуки більш ніж на 7 ккал/ моль, вважались енергетично нестійкими та вилучались 3 подальшого аналізу. Крім точності класифікації фармакофорної моделі визначали також ступінь перекриття активних сполук. Вищі значення цього показника означають кращий ступінь узгодження конформацій у ряду сполук, які проявляють біологічну активність.

Результати та їх обговорення. Проведене моделювання виявило 5 можливих фармакофорних моделей 3 різною точністю класифікації та ступенем перекривання. Усі моделі характеризувалися набором з чотирьох фармакофорних центрів. Додавання п'ятого центру до будь-якої моделі не покращувало досягнутої цією моделлю точності класифікації. Чотири моделі мали однаковий набір фармакофорних центрів (одне ароматичне кільце, одна проекція донора водневого зв'язку, дві проекції акцепторів водневого зв’язку), але різні координати цих центрів (таблиця). Це стало причиною різного ступеня перекриття активних сполук у цих моделях, а також точності класифікації. Відразу три моделі продемонстрували найвищі досягнуті показники точності класифікації - 0,74. Такий результат зумовлений значною структурною подібністю в досліджуваному ряду тіазолів і тіадіазолів. Надалі для аналізу вибрано модель 3 найвищою точністю класифікації та найкращим ступенем перекриття активних сполук.

Краща фармакофорна модель містить, крім ароматичного ядра, одну проекцію донора водневого зв'язку та дві проекції акцепторів водневого зв'язку. Фізичний зміст проекції донора водневого зв'язку полягає в ідентифікації такого місця в просторі поблизу атома гідрогену з частковим позитивним зарядом, при потраплянні в яке гетероатому з неспареною електронною парою (зазвичай оксигену або нітрогену) утвориться водневий зв'язок між цим гетероатомом і гідрогеном. Фізичний зміст проекції акцептора водневого зв'язку полягає в ідентифікації такого місця у просторі поблизу гетероатому з неспареною парою електронів (нітроге-

Таблиця

Характеристики розроблених фармакофорних моделей для виявлення та скринінгу діуретичної дї серед похідних тіазолу та тіадіазолу

\begin{tabular}{|c|c|c|c|}
\hline № & Перелік фармакофорних центрів & $\begin{array}{c}\text { Ступінь взаємного } \\
\text { перекриття актив- } \\
\text { них сполук }\end{array}$ & $\begin{array}{c}\text { Точність } \\
\text { класифікації }\end{array}$ \\
\hline 1 & $\begin{array}{l}\text { Одне ароматичне кільце, одна проекція } \\
\text { донора водневого зв'язку, дві проекції } \\
\text { акцепторів водневого зв'язку }\end{array}$ & 9,30 & 0,74 \\
\hline 2 & $\begin{array}{l}\text { Одне ароматичне кільце, одна проекція } \\
\text { донора водневого зв'язку, дві проекції } \\
\text { акцепторів водневого зв'язку }\end{array}$ & 9,19 & 0,74 \\
\hline 3 & $\begin{array}{l}\text { Одна гідрофобна область, одна проекція } \\
\text { донора водневого зв'язку, дві проекції } \\
\text { акцепторів водневого зв'язку }\end{array}$ & 8,60 & 0,74 \\
\hline 4 & $\begin{array}{l}\text { Одне ароматичне кільце, одна проекція } \\
\text { донора водневого зв'язку, дві проекції } \\
\text { акцепторів водневого зв'язку }\end{array}$ & 8,64 & 0,63 \\
\hline 5 & $\begin{array}{l}\text { Одне ароматичне кільце, одна проекція } \\
\text { донора водневого зв'язку, дві проекції } \\
\text { акцепторів водневого зв'язку }\end{array}$ & 8,60 & 0,63 \\
\hline
\end{tabular}


ну, оксигену), при потраплянні в яке електронодефіцитного атома гідрогену утвориться водневий зв'язок між цим гідрогеном і гетероатомом. Краща фармакофорна модель має планарну структуру, тобто всі чотири фармакофорні центри містяться в одній площині. На краях фармакофорної моделі знаходяться дві проекції акцептора водневого зв'язку та одна проекція донора водневого зв'язку, утворюючи трикутник зі сторонами 4,45 $\AA, 6,86 \AA$ і 8,44 $\AA$ (рис. 2, 3). Причому найкоротша сторона з'єднує саме проекції акцепторів водневого зв'язку. Фармакофорний центр ароматичного ядра знаходиться поблизу найдовшої сторони цього трикутника, відхиляючись від неї всього на $0,32 \AA$.

Проведено дослідження узгодженості кількох активних сполук з кращою фармакофорною моделлю. У цих сполуках ключову роль для прояву активності відіграє тіадіазольне ядро та амідна група, приєднана $\mathrm{N}$-кінцем до 2-го положення тіадіазолу (рис. 4). Так, однією з проекцій акцептора водневого зв'язку є проекція саме атома нітрогену в 4-му положенні тіадіазольного кільця. Цей атом нітрогену має вільну пару електронів, не задіяних в ароматичній системі, і здатен утворювати водневий зв'язок у разі наявності полярного атома гідрогену в околиці. Слід відзначити, що структури ацетазо-

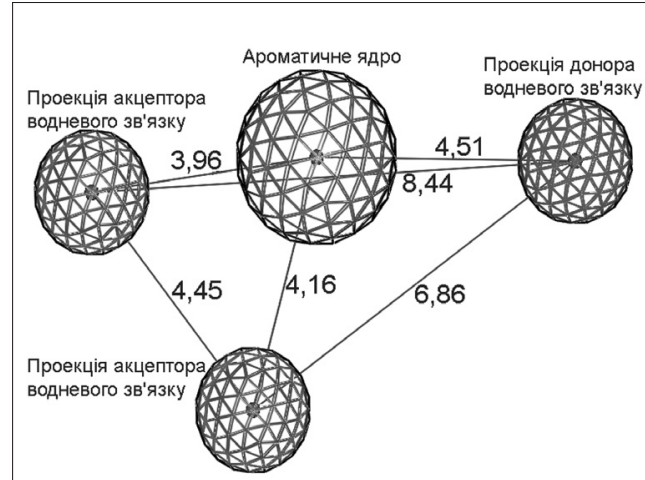

Рис. 2. Схела кращої фарлакофорной моделі Примітка. Числами позначено відстані між відповідними фармакофорними иентрами в А.

ламіду та N-(5-метил-1,3,4-тіадіазол-2іл)пропанаміду суттєво відрізняються лише замісником у 5-му положенні тіадіазольного фрагмента. Метильна група N-(5-метил-1,3,4-тіадіазол-2-іл) пропанаміду має слабкі позитивні індуктивний і мезомерний (через ефект Бейкера-Натана [9]) ефекти, що збільшує частковий заряд на атомі нітрогену в 4-й позиції та полегшує утворення ним водневих зв'язків. Тоді як сульфонамідна група в ацетозоламіді чинить сильний негативний індуктивний ефект i слабкий негативний мезомерний ефект, зменшуючи частковий заряд на атомі нітрогену в 4-й позиції та утруднюючи утворення ним водневих зв'язків. Саме ці особливості можуть виявитись причиною кращої взаємодії
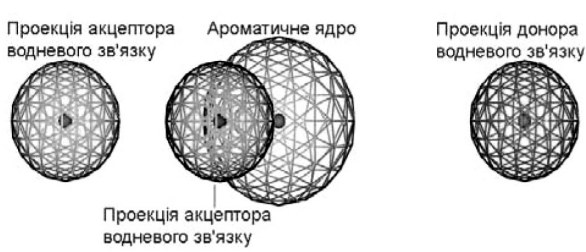

фронтальна проекція
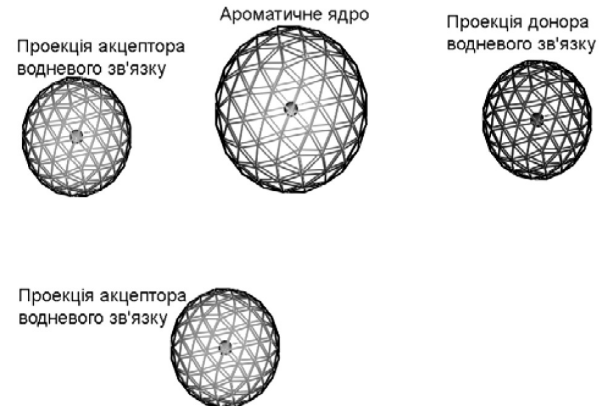

горизонтальна проекція

Рис 3. Геолетрія кращой фарлакофорной моделі в трьох проекиіях

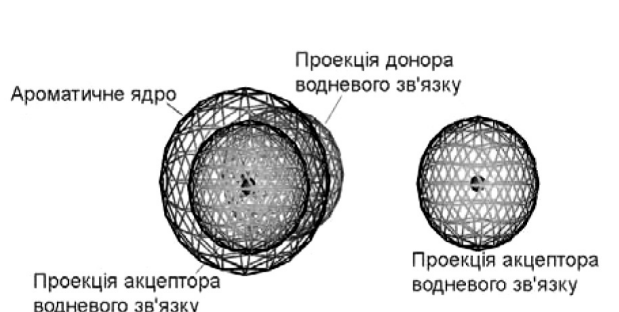

профільна проекція 


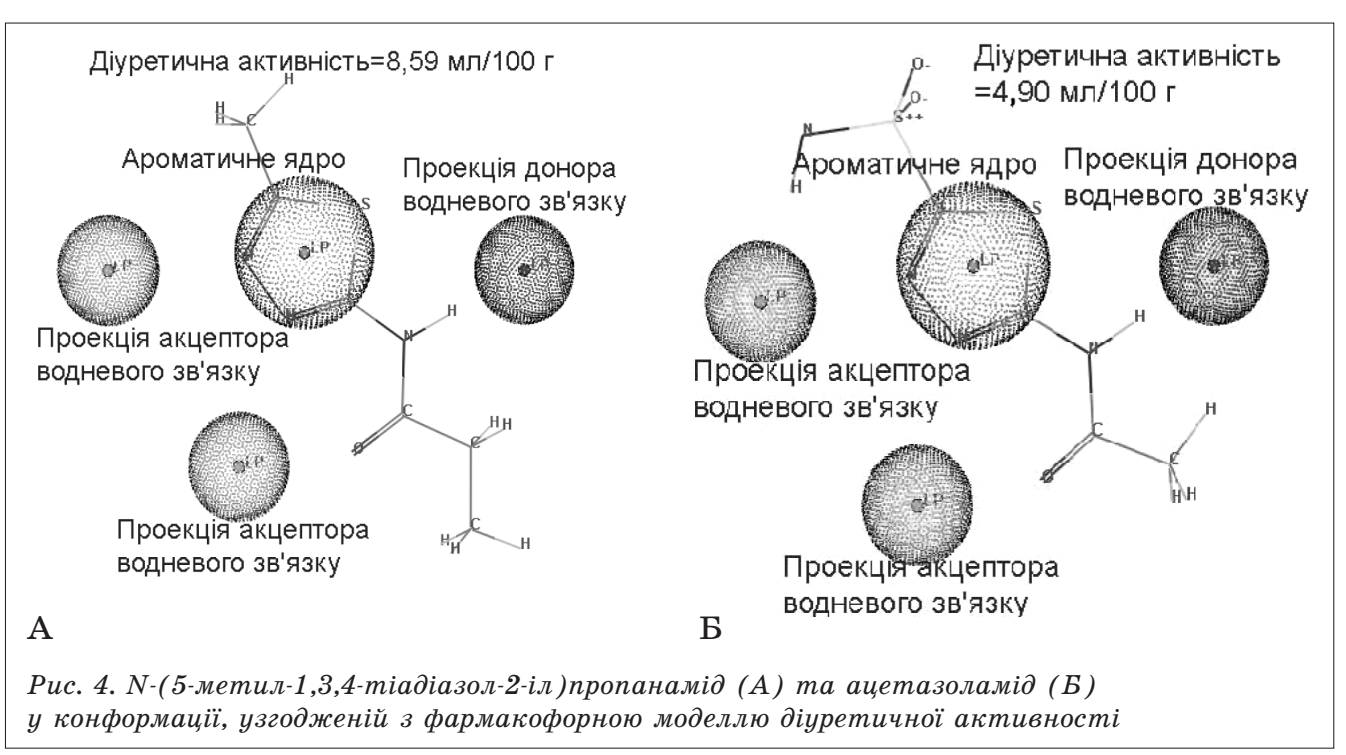

3 біомішенню та, як наслідок, сильнішого діуретичного ефекту в $\mathrm{N}$-(5-метил1,3,4-тіадіазол-2-іл)пропанаміду порівняно $з$ ацетазоламідом. Інша проекція водневого зв'язку розташована в позиції, яка дозволяє утворювати водневий зв'язок із оксигеном амідної групи (сильніший) та, як резонансний варіант, із нітрогеном у 3 -му положенні тіадіазольного кільця (слабший). Цей компонент є спільним для N-(5-метил-1,3,4тіадіазол-2-іл)пропанаміду, ацетазоламіду та більшості активних сполук у досліджуваному нами ряду. Донором водневого зв'язку в активних сполуках виступає нітроген амідної групи. Приєднані до цього атома карбонільний i тіадіазольний фрагменти відбирають від нього електронну густину через свій мезомерний ефект. Наслідком цього $€$ значний додатний частковий заряд на зв'язаному з ним атомі гідрогену, який завдяки цьому частковому заряду утворюватиме водневі зв'язки 3 більшою енергією.

\section{Висновки}

Фармакофорне моделювання ряду похідних тіазолу та тіадіазолу як потенційних діуретиків, активність яких перевірена in vivo, дало змогу виділити можливий фармакофор, що складається з ароматичного кільця, двох проекцій акцептора водневого зв'язку й однієї проекції донора водневого зв'язку. Точність класифікації активних i неактивних сполук даною моделлю становить 0,74 , дана модель може надалі застосовуватись для in silico скринінгу молекулярних баз даних з метою ідентифікації віртуальних хітів. Порівнюючи узгодженість $\mathrm{N}$-(5-метил-1,3,4-тіадіазол-2-іл) пропанаміду та ацетазоламіду 3 розробленою фармакофорною моделлю, визначено модулюючий вплив замісника в 5-му положенні тіадіазольного кільця на силу діуретичного ефекту in vivo. Отримані дані свідчать, що замісники 3 позитивним індуктивним i мезомерним ефектом у цьому положенні можуть сприяти кращій афінності досліджуваних молекул до їхньої біомішені (якою з найбільшою ймовірністю $є$ карбоангідраза). Подальші модифікації фрагментів у 5-му положенні тіадіазольного скаффолду $\epsilon$ перспективним напрямом для розширення бібліотеки потенційних діуретичних сполук.

1. Computational methods in drug discovery. G. Sliwoski, S. Kothiwale, J. Meiler, E. W. Lowe Pharmacol Rev. 2014. V. 66. P. 334-95. https://doi.org/10.1124/pr.112.007336.

2. Computational approaches in target identification and drug discovery. T. Katsila, G. A. Spyroulias, G. P. Patrinos, M.-T. Matsoukas. Computational and Structural Biotechnology Journal. 2016. V. 14 P. 177-184. https://doi.org/10.1016/j.csbj.2016.04.004 
3. Sheng-Yong Yang. Pharmacophore modeling and applications in drug discovery: challenges and recent advances. Drug Discovery Today. 2010. V.15, Issues 11-12. P. 444-450. https://doi. org/10.1016/j.drudis.2010.03.013.

4. Gao Q., Yang L, Zhu Y. Pharmacophore based drug design approach as a practical process in drug discovery. Current Computer-Aided Drug Design. 2010. V. 6 (1). P. 37-49. https://doi. org/10.2174/157340910790980151.

5. Horvath D. Pharmacophore-based virtual screening. Methods Mol Biol. 2011. 672. P. 261-98. https://doi.org/10.1007/978-1-60761-839-3_11.

6. Берхин Е. Б. Методы изучения действия новых химических соединений на функцию почек. Хим. фарм. журн. 1977. Т 11, № 5. С. 3-11.

7. Доклінічні дослідження лікарських засобів (методичні рекомендації); за редакцією чл.-кор. АМН України О. В. Стефанова. Київ : ВД « Авіцена», 2001. 528 с. (С. 84-90).

8. Chemical Computing Group Inc. MOE 2007.09 (Molecular Operating Environment software). URL: http://www.chemcomp.com.

9. Baker J. W., Nathan W. S. The mechanism of aromatic side-chain reactions with special reference to the polar effects of substituents. Part V. The polar effects of alkyl groups. Journal of the Chemical Society. 1935. 429. P. 1844-1847.

\section{I. В. Драпак \\ Фармакофорне моделювання діуретичної активності похідних 1,3-тіазолу та 1,3,4-тіадіазолу}

Фармакофорне моделювання є одним з перспективних напрямів комп'ютерної підтримки розробки ліків (Computer-Aided Drug Design). Цей метод дозволяє встановити набір та взаємне розташування специфічних молекулярних фрагментів, які необхідні для прояву біологічної активності.

Мета дослідження - фармакофорне моделювання похідних 1,3-тіазолу та 1,3,4-тіадіазолу для цілеспрямованого пошуку потенційних діуретиків.

Для моделювання фармакофора, відповідального за прояв діуретичної активності в ряду досліджених сполук, використовували комп'ютерну програму MOE (Molecular Operating Environment).

Фармакофорне моделювання ряду похідних тіазолу та тіадіазолу як потенційних діуретиків, активність яких встановлена in vivo, дало змогу виділити можливий фармакофор, що складається 3 ароматичного кільця, двох проекцій акцептора водневого зв'язку та однієї проекції донора водневого зв'язку. Точність класифікації активних і неактивних сполук даною моделлю становить 0,74, дана модель може надалі застосовуватись для in silico скринінгу молекулярних баз даних з метою ідентифікації віртуальних хітів. Порівнюючи узгодженість N-(5-метил-1,3,4-тіадіазол-2-іл)пропанаміду та ацетазоламіду з розробленою фармакофорною моделлю, визначено модулюючий вплив замісника в 5-му положенні тіадіазольного кільця на силу діуретичного ефекту in vivo. Отримані дані свідчать, що замісники з позитивним індуктивним і мезомерним ефектом у цьому положенні можуть сприяти кращій афінності досліджуваних молекул до їхньої біомішені (якою з найбільшою ймовірністю є карбоангідраза). Подальші модифікації фрагментів у 5-му положенні тіадіазольного скаффолду $є$ перспективним напрямом для розширення бібліотеки потенційних діуретиків.

Ключові слова: фармакофорне моделювання, похідні тіазолу та тіадіазолу, діуретична активність

\section{И. В. Драпак \\ Фармакофорное моделирование диуретической активности производных 1,3-тиазола и 1,3,4-тиадиазола}

Фармакофорное моделирование является одним из перспективных направлений компьютерной поддержки разработки лекарств (Computer-Aided Drug Design). Этот метод позволяет установить набор и взаимное расположение специфических молекулярных фрагментов, которые необходимы для проявления биологической активности.

Цель исследования - фармакофорное моделирование производных 1,3-тиазола и 1,3,4-тиадиазола для целенаправленного поиска потенциальных диуретиков.

Для моделирования фармакофора, ответственного за проявление диуретической активности в ряду исследованных соединений, использовали компьютерную программу MOE (Molecular Operating Environment).

Фармакофорное моделирование ряда производных 1,3-тиазола и 1,3,4-тиадиазола как потенциальных диуретиков, активность которых установлена in vivo, позволило установить возможный фармакофор, состоящий из ароматического кольца, двух проекций акцептора водородной связи и одной проекции донора водородной связи. Точность классификации активных и неактивных соединений данной модели составляет 0,74 , данная модель может в дальнейшем применяться для in silico скрининга молекулярных баз данных с целью идентификации виртуальных хитов. Сравнивая согласованность N-(5-метил-1,3,4-тиадиазол-2-ил)пропанамида и ацетазоламида с разработанной фармакофорной моделью, установлено модулирующее влияние заместителя в пятом положении тиадиазольного кольца на силу диуретического эффекта in vivo. Полученные данные свидетельствуют, 
что заместители с положительным индуктивным и мезомерным эффектом в этом положении могут способствовать лучшей аффинности исследуемых молекул к их биомишени (которой с наибольшей вероятностью является карбоангидраза). Дальнейшие модификации фрагментов в пятом положении тиадиазольного скаффолда являются перспективным направлением для расширения библиотеки потенциальных диуретиков.

Ключевые слова: фармакофорное моделирование, производные 1,3-тиазола и 1,3,4-тиадиазола, диуретическая активность

\section{V. Drapak \\ Pharmacophore modeling of diuretic activity of 1,3-thiazole and 1,3,4-thiadiazole derivatives}

Pharmacophore modeling is one of the most promising areas of computer-aided drug design. This method allows us to establish the set and the relative location of specific molecular fragments that are necessary for the manifestation of biological activity.

The purpose of the work is the pharmacophore modeling of derivatives of 1,3-thiazole and 1,3,4-thiadiazole for the purposeful search for potential diuretics.

To model the pharmacophore responsible for displaying diuretic activity in a number of investigated compounds, the computer program MOE (Molecular Operating Environment) was used.

The pharmacophore modeling of 1,3-thiazole and 1,3,4-thiadiazole derivatives as potential diuretics with conformed activity in vivo, allowed to establish a possible pharmacophore consisting of an aromatic ring, two projections of the hydrogen acceptor and one projection of a hydrogen bond donor. The accuracy of the classification of active and inactive compounds by this model is 0.74 ; this model can then be used for in silico screening of molecular databases for the purpose of virtual hits identifying. Comparing the coherence of $\mathrm{N}$-(5-methyl-1,3,4-thiadiazol-2-yl)propanamide and acetazolamide with the developed pharmacophore model, the modulating influence of the substituent in the $5^{\text {th }}$ position of the thiadiazole ring. On the strength of the diuretic effect in vivo was established. The data obtained indicate that substituents with a positive inductive and mesomeric effect in this position can contribute to better affinity of the molecules being studied to their biotarget (which is most probably to be carboanhidrase). Further modifications of the fragments in the $5^{\text {th }}$ position of the thiadiazole scaffold are a promising direction for expanding the library of potential diuretics.

Key words: pharmacophore modeling, derivatives of 1,3-thiazole and 1,3,4-thiadiazole, diuretic activity

ORCID ID aвTopa:

Драпак I. В. (ORCID ID 0000-0002-6830-2908)

Надійшла: 30 квітня 2019 р.

Прийнята до друку: 23 травня 2019 р.

Контактна особа: Драпак Ірина Володимирівна, кандидат фармацевтичних наук, доцент, кафедра загальної, біонеорганічної та фізколоїдної хімії, Львівський національний медичний університет імені Данила Галицького, буд. 69, вул. Пекарська, м. Львів, 79010.

Тел.: + 3803227548 87. Електронна пошта: iradrapak@ukr.net 